\title{
Characterization of minothems at Libiola (NW Italy): morphological, mineralogical, and geochemical study
}

\author{
Cristina Carbone $^{1^{*}}$, Enrico Dinelli², and Jo De Waele ${ }^{2}$ \\ ${ }^{1}$ DISTAV, Dipartimento di Scienze della Terra, dell'Ambiente e della Vita, Università di Genova, Corso Europa 26, Genova, Italy \\ ${ }^{2}$ BiGeA, Dipartimento di Scienze Biologiche, Geologiche e Ambientali, Alma Mater Studiorum, Università di Bologna, Italy
}

\begin{abstract}
The aim of this study is to characterize in detail, the mineralogy of different-shaped concretions as well as to investigate the physico-chemical parameters of the associated mine drainage and drip waters in the Santa Barbara level of the Libiola Mine (NW Italy) by several geochemical and mineralogical techniques. Under the term "minothems" we are grouping all those secondary minerals that occur under certain form or shape related to the conditions under which they formed but occur in a mine, or in any artificial underground environment (i.e., "mine speleothems"). Different types of minothems (soda straw stalactites, stalactites, and draperies) were sampled and analyzed. Mineralogical results showed that all the samples of stalactites, stalagmite and draperies are characterized by poorly crystalline goethite. There are significant differences either in their texture and chemistry. Stalactites are enriched in $\mathrm{Zn}, \mathrm{Cd}$, and $\mathrm{Co}$ in respect to other minothems and show botryoidal textures; some of these exhibit a concentric layering marked by the alternation of botryoidal and fibrous-radiating textures; the draperies are enriched in $\mathrm{V}$ and show aggregates of sub-spheroidal goethite forming compact mosaic textures. Geochemical investigations show that the composition and physico-chemical parameters of mine drainage and drip waters are different from the other acidic mine water occurrences in different areas of the Libiola Mine, where minothems are less abundant. All mine water samples contain $\mathrm{Cu}, \mathrm{Ni}$, and $\mathrm{Zn}$ in appreciable levels, and the physico-chemical conditions are consistent with the stability of ferrihydrite, which however tends to transform into goethite upon ageing.
\end{abstract}

Keywords: $\quad$ minothems, stalactite, stalagmite, goethite-ferrihydrite, Libiola Mine, Italy

Received 29 July 2015; Revised 13 May 2016; Accepted 15 May 2016

Citation: Carbone C., Dinelli E. and De Waele J., 2016. Characterization of minothems at Libiola (NW Italy): morphological, mineralogical, and geochemical study. International Journal of Speleology, 45 (2), 171-183. Tampa, FL (USA) ISSN 0392-6672

http://dx.doi.org/10.5038/1827-806X.45.2.1944

\section{INTRODUCTION}

Speleothems are considered secondary mineral deposits formed by physical-chemical reactions from a primary mineral within the natural cave environment assuming a typical shape, depending on the environmental conditions in which they form (Hill \& Forti, 1997). Most speleothems typically form from the precipitation of $\mathrm{CaCO}_{3}$ (either calcite or aragonite) in caves developed in carbonate bedrock. The term speleothem refers to the mode of occurrence of a mineral, i.e. its morphology, and not to its mineralogical or chemical composition (Hill \& Forti, 1997). Stalactites and stalagmites are speleothem types formed primarily by dripping water, elongated in the vertical direction of dripping and typically exhibit growth rates in the range of $0.01-1.0 \mathrm{~mm}$ per year (Perrette \& Jaillet, 2010), depending on flow rate, cave temperature, and the saturation of the drip water.
Seasonal changes in water availability may lead to the formation of annual layers, the thickness of which may vary as a response to precipitation changes at the surface (Baker et al., 2008; Fairchild \& Baker, 2012).

Speleothems can also be composed of other carbonates, oxides, hydroxides, sulfides, sulfates, and silicates (Hill \& Forti, 1997; Onac \& Forti, 2011). Oxide and hydroxide stalactites, stalagmites, and flowstones are common in mine tunnels in supergene settings of ore deposits (Campbell \& Barton, 1996; Jebrak et al., 1996), in lava tube systems (McFarlane et al., 2004; de los Rìos et al., 2011; Daza \& Bustillo, 2015) but also occur in natural carbonate caves (Onac et al., 2001, 2014; Frierdich et al., 2011; Frierdich \& Catalano, 2012). In particular Fe and Mn deposit have been recognized in many cave environments and their formation is typically mediated by microbial processes (Kasama \& Murakami, 2001; Northup \& Lavoie, 2001; Barton \& Northup, 2007; Baskar et al., 
2008; de los Rìos et al., 2011; Frierdich et al., 2011; Daza \& Bustillo, 2015).

We define "minothems" as secondary mineral concretions forming in an artificial underground void, such as a mine or any other kind of tunnel (i.e. roman aqueduct, catacomb, highway tunnel, etc.). These voids can be carved in carbonate rocks, but can often be hosted in different geological materials, such as volcanic rocks (Tuccimei et al., 2006), granites, or any other type of solid rock. Only few data were published on Acid Mine Drainage (AMD) environments in which minothems mainly occur as Fe-rich minerals (Campbell \& Barton, 1996; Jebrak et al., 1996; Banfield et al., 2000; Nordstrom et al., 2000; Onac et al., 2013; Peterson, 2003; Jamieson et al., 2005; Cabała \& Bzowska, 2008; Arnold et al., 2011; Ara et al., 2013). In this case also the term "siderothems" has been used, but minothems should be preferred being a more general term regardless of their chemistry.

Although much information is available on the characterization and mode of occurrence of calcite and aragonite stalactites and stalagmites, the textural and mineralogical characteristics of concretions formed in AMD environment (minothems) is not documented in much detail.

The aim of this work is to characterize the different morphology and mineral chemistry of iron hydroxide minothems that form in the abandoned Libiola
Fe-Cu-sulfide mine located about $8 \mathrm{~km} \mathrm{NE}$ from the town of Sestri Levante (eastern Liguria, Italy) (Fig. 1). Nowadays, the site is characterized by active and intense AMD processes triggered by the supergene interaction between sulfide-rich mineralizations and atmospheric agents (Dinelli et al., 1998; 2001; Dinelli \& Tateo 2002; Marini et al., 2003; Carbone et al., 2005; 2013). Sulfate-rich acid waters circulate within the underground excavations, in waste rock dumps and in the surrounding streams and runoff channels. As a consequence, large quantities of Fe-rich secondary minerals are produced; they occur both as muds and soft crusts inside the mine, and as loose suspensions associated with overland flows of mine waters (Marescottti et al., 2012). Waters percolating inside the galleries form numerous decorative dripstone features that coat the walls, ceilings, and floors of the mine creating a colourful array of yellow, orange, green, brown, and black minothems, mainly represented by soda straws, draperies, stalactites and stalagmites. Among the 27 underground levels of the Libiola Mine only very few have accessible entrances. The Santa Barbara level is partially preserved up to $1 \mathrm{~km}$ from its access and it was thus chosen for this study.

In this paper, we present the results of a detailed mineralogical and geochemical study of the different types of textures of Fe-rich minothems and their feeding waters and discuss their minerogenetic evolution.

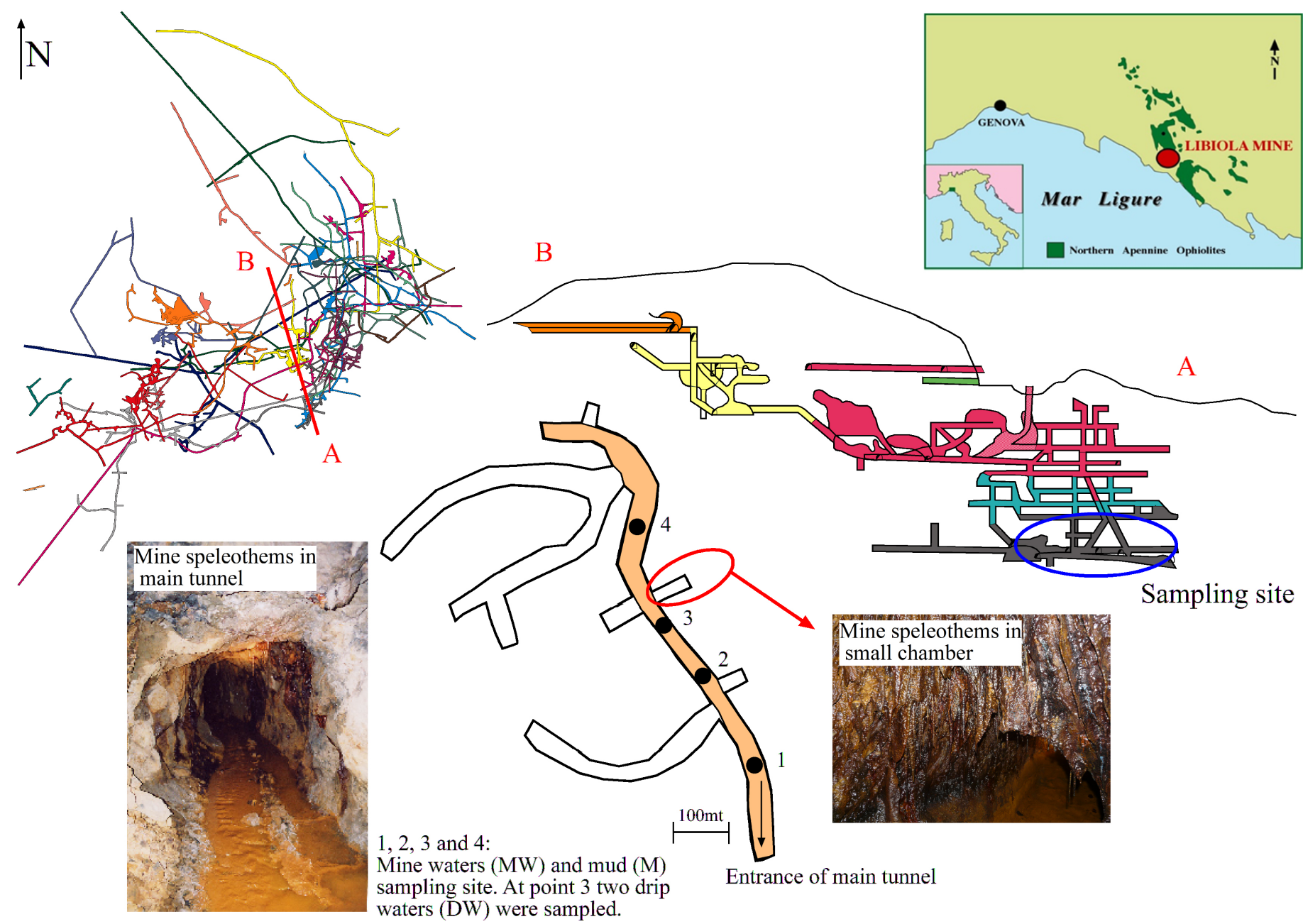

Fig. 1. Location of the Libiola Mine and the main ophiolite bodies and schematic planimetric view of the mine galleries and Profile AB (without scale) indicating the sampling site in the Santa Barbara level; the main tunnel in which ochreous muds and acidic waters have been sampled is indicated (centre). 


\section{MINOTHEMS}

The Santa Barbara level of the Libiola Mine hosts a wide variety of minothems representative of what has been found elsewhere in artificial underground excavations (Fig. 2). Minothems are the counterpart of speleothems in natural caves, and generally show the same morphologies. However, the petrographical and geological differences of the host rock can cause significant distinctions in mineralogy, colour and shape of the minothems when compared to speleothems. Mine adits host soda straws, stalactites, draperies, stalagmites, columns, flowstones, gours, but can also contain pearls, rafts, coralloids (popcorn), moonmilk, and helictites (Fig. 3a-c). These are often composed of exotic minerals, mainly sulfates (melanterite, gypsum, epsomite) some of which are rather uncommon (Onac et al., 2003; Cabała \& Bzowska, 2008; Gàzquez et al., 2014) and oxides-hydroxides (Banfield et al., 2000). Beside formations typical also for natural caves, some concretions are rather unique to these mine adits. Often the special geochemical environment, with low $\mathrm{pH}$ and high concentrations in metals in the percolating waters create the ideal place for specific microorganisms to proliferate. This bacterial activity is believed to enhance the precipitation of the ochreous concretions (de los Rios et al., 2011; Daza \& Bustillo, 2015). Typical minothems related to microbial activity are the snottites (Fig. 3d), abundant also in sulfidic cave systems (Hose \& Pisarowicz, 1999; Jones et al., 2010) and the jellystones (Fig. 3e). These last are gelatinous flowstones containing large quantities of water and poorly crystallized minerals. They often have a surface made out of a series of minigours cascading downward (Fig. 3f). During drier periods their surface can get more solid, but when perforated the jellystone reveals its gelatinous characteristics. In Libiola Mine one of these jellystones ends in a small pool, at whose surface native copper is precipitating (Fig. 3g), most probably with the mediation of microorganisms.

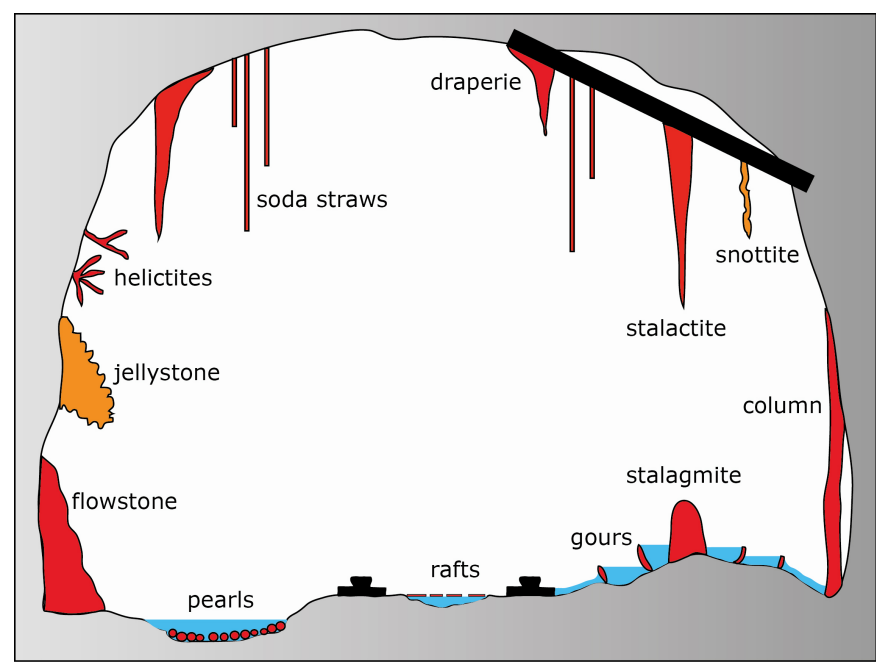

Fig. 2. Schematic representation of a mine tunnel with the different kinds of minothems. The orange biomediated forms are those typically found in a mine environment.
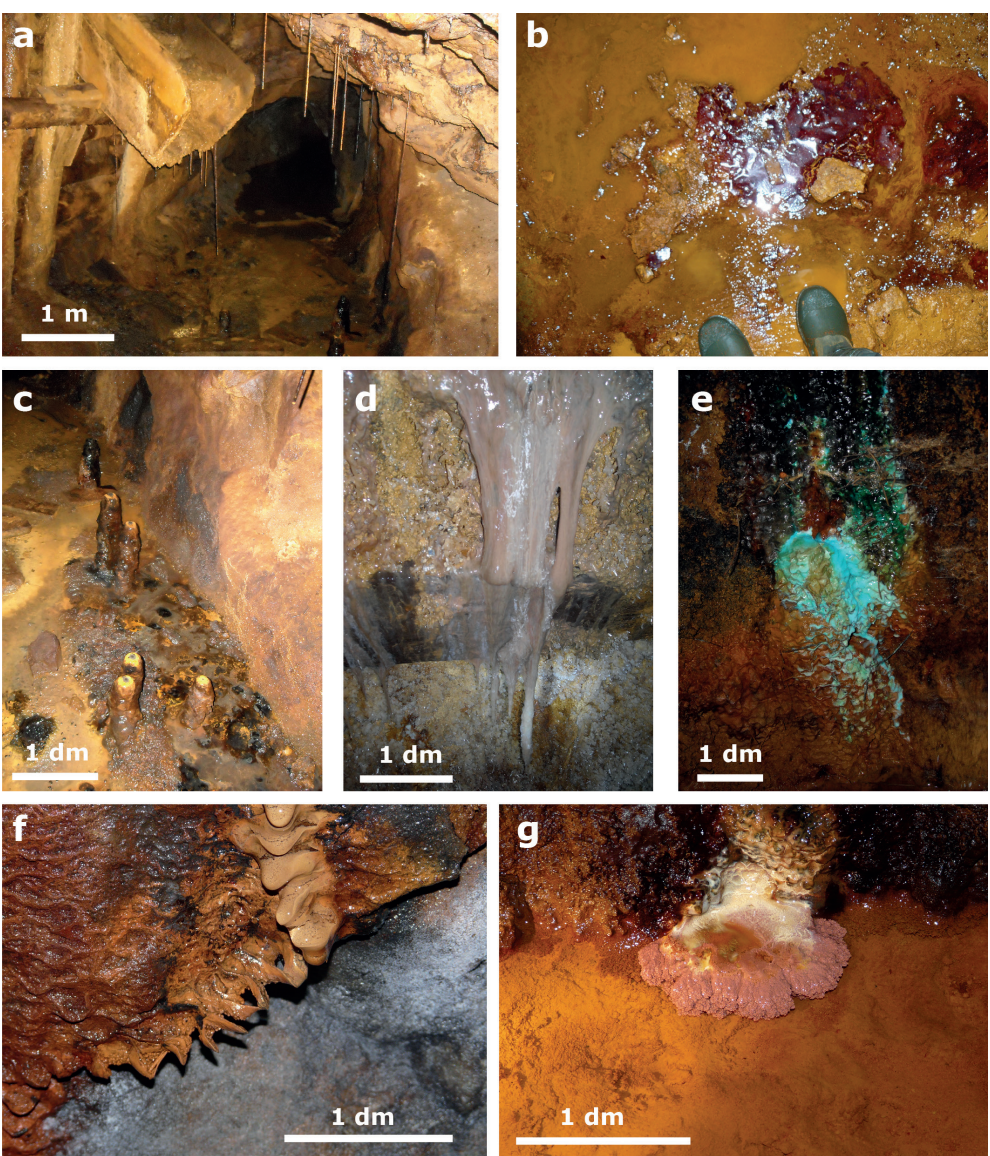

Fig. 3. Minothems in Libiola Mine: a) General view of a mine adit with equipment and the soda straw stalactites hanging from the roof; b) Rafts; c) Stalagmites; d) Snottites; e) Jellystone; f) Microgours (detail of a jellystone); g) Native copper.

\section{EXPERIMENTAL WORK}

\section{Sample location}

The Libiola mining area develops along 27 levels, contains 7 open pits, and over 30 vertical shafts. The sulfide ore occurs within the Jurassic ophiolites of the Northern Apennines that are considered to be remnants of the oceanic crust underlying the western limb of the Jurassic Tethys (Abbate et al., 1980; Piccardo et al., 2002; Piccardo, 2016) which consist of an ultramafic/ gabbroic basement overlain by a volcano-sedimentary sequence, that in the Libiola area comprises tectonicand sedimentary-ophiolitic breccias, pillow basalts, and cherts. This deposit has been classified as a stratabound volcanic-associated massive sulfide deposit and consists of massive sulfide lenses in the upper part of a pillow lava flow, which is underlain by gabbro and serpentinite (Galli \& Penco, 1996). At the footwall of the massive ore lenses, the sulfides infiltrated fragmented pillows, giving rise to a coarse network ore that grades downward into minute veins and fissures of stringer ore, within completely chloritized basalt. Sub-economic disseminated mineralizations are also present in the pillow basalts and serpentinized ultramafics. The sulfide assemblage in the Libiola stratabound deposit consists of pyrite and chalcopyrite with subordinate pyrrhotite and sphalerite, in a gangue of quartz, calcite and chlorite. Pyrite with minor chalcopyrite and rare sphalerite predominate in the stringer ore. Accessory titanite, Fe-Ti oxides, electrum, acanthite, native silver and uraninite are commonly found in the chlorite-quartz-calcite matrix of the ore (Zaccarini \& Garuti, 2008). 
There is an extensive occurrence of mine wastes scattered throughout the entire mining area, and minor waste-rock and tailing dumps are mainly located close to the main mine adits.

The sampling site is the Santa Barbara Gallery (Fig. 1), which is the oldest underground excavation of the Libiola Mine, being started in 1859 at the beginning of the official exploitation. Its adit is located in the southern part of the mining area and the entrance is characterized by a well-preserved brick arch. The gallery crosses for the first $150 \mathrm{~m}$ strongly tectonized serpentinites and then continues within the pillow basalt. The massive mineralizations were located along the contact of these two lithologies, and this is where the main concentration of minothems has developed. The Santa Barbara level is connected with many other levels through shafts and winzes (Fig. 1). Along the main tunnel of S. Barbara level (Fig. 1) there is a constant presence of ochreous muds associated with weakly acidic waters $(5.8<\mathrm{pH}<6.1)$, and minothems are abundant.

Four sampling sites were chosen for collecting the muds and associated waters, whereas two different sites were selected for the sampling of various minothems (Fig. 1).

Water and mud sampling occurred along the entire tunnel. Mine water samples (labelled MW1, MW2, MW3, MW4) were collected using a plastic syringe trying to take only the clean water and $\mathrm{pH}, \mathrm{Eh}, \mathrm{T}$ and electric conductivity (EC) were measured in situ. Moreover, in MW3 sampling site two drip waters (DW) were taken. Drip waters were centrifuged and the remnant colloidal solid fraction was analysed using the TEM technique. Mud samples (labelled M1 M2, M3, M4) were collected by suctioning the loose flocs using a plastic syringe. Moreover, we collected drip waters from stalactites in plastic containers and $\mathrm{pH}$, Eh, T, and EC were measured in situ.

Mud samples were filtered through a $16 \mu \mathrm{m}$ membrane filter and then dried at room temperature for 48 hours for X-ray powder diffraction (XRPD) analyses.

Minothems were sampled in two different environments (Fig. 1): 1) along the main tunnel and 2) in a small chamber localised in a short lateral closed tunnel. One sample of stalagmite (STG, Fig. 4a) and one of stalactite (ST, Fig. 4b) were collected in the main tunnel. In the small lateral chamber numerous minothems with different morphologies almost completely cover the roof. Two samples of draperies (DRP and VEL, Fig. 4c-d) were collected in this environment. In this chamber, no muds, waters and drip waters were present. A fallen piece of soda straw was also sampled for chemical analyses.

\section{Mineralogical and chemical analyses on solid samples}

The stalactite (ST), stalagmite (STG) and draperies (DRP and VEL) were characterized using XRPD, SEM (Scanning Electron Microscopy), ICP-AES (Inductively Coupled Plasma-Atomic Emission Spectrometry) and ICP-MS (Inductively Coupled Plasma-Mass Spectrometry) analyses.

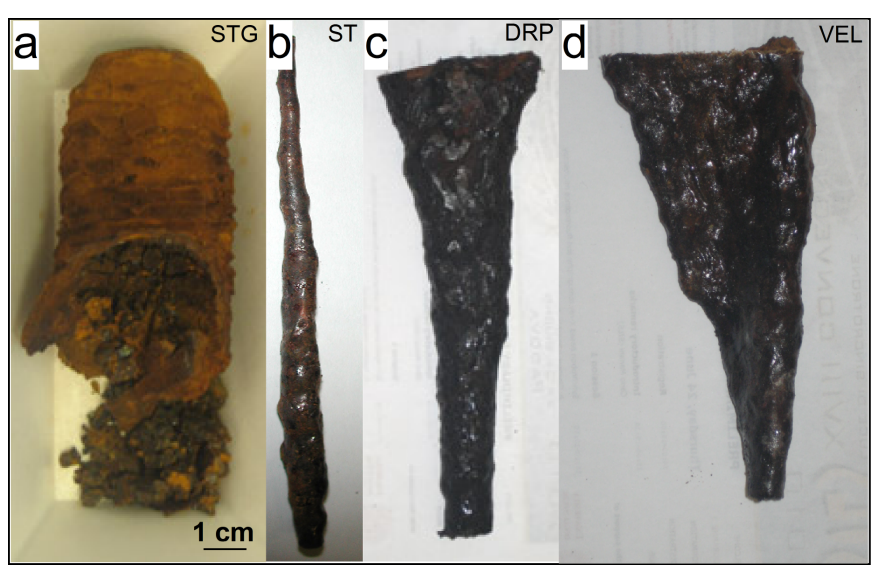

Fig. 4. Investigated samples: a) Stalagmite STG; b) Stalactite ST; c) Drapery DRP; d) Drapery VEL.

The XRPD analyses were carried out (DISTAV, Genova University, Italy) using a Philips PW3710 diffractometer (current $20 \mathrm{~mA}$, voltage $40 \mathrm{kV}$, range $2 \theta 5-80^{\circ}$, step size $0.02^{\circ} 2 \theta$ time per step 2 s) equipped with a Co-anode and interfaced with Philips High Pert software package for data acquisition and mineral identification (using PDF file as database).

Scanning electron microprobe analyses were performed with a "SEM VEGA3 TESCAN" (DISTAV, Genoa University) operated at $20 \mathrm{kV}$ and equipped with an "EDAX-APOLLO_X DPP3" energy-dispersive (EDS) X-ray spectrometer. Data acquisition and elaboration used the TEAM EDS software.

The bulk-element composition (major, minor, and trace elements) of minothems was assessed by acid digestion $(0.5 \mathrm{~g}$ powder leached with $3 \mathrm{~mL}$ 2:2:2 $\mathrm{HCl}-\mathrm{HNO}_{3}-\mathrm{H}_{2} \mathrm{O}$ at $95^{\circ}$ for $1 \mathrm{~h}$ ) followed by ICPAES and ICP-MS analyses (ACME Laboratory, Bureau Veritas, Vancouver, Canada).

Mud samples were analyzed using XRPD and ICP-MS techniques whereas the solid fraction of drip waters was analyzed by TEM (Trasmission Electron Microscopy). The TEM analyses were carried out with a Jeol JEM-2010 TEM at $200 \mathrm{kV}$ (DCCI, Department of Chemical and Chemical Industry of Genova University). The samples were prepared by grinding selected amounts of the specimens, which were ultrasonically dispersed in alcohol and then deposited on porous $\mathrm{C}$-coated $\mathrm{Cu}$ grids. The analytical electron microscope (AEM) investigations were performed using an X-ray EDS system (Oxford Pentafet). The mineralogical identification of the investigated solid phases was made through interpretation of Selected Area Electron Diffraction (SAED) patterns.

\section{Water analyses}

As already stated, in connection with the sampling of stalactites and muds, water flowing in the mine galleries and drip waters were also collected. T, pH, Eh and EC were measured in the field. Each sample was collected and stored using three different treatments that consisted in filtering, filtering and acidification $\left(10 \%\right.$ vol. $\left.\mathrm{HNO}_{3}\right)$ and no-treatment. Water samples were analysed (BiGeA, Bologna University) by titration $\left(\mathrm{HCO}_{3}{ }^{-}\right)$, IC (Ion Chromatography) $\left(\mathrm{F}^{-}, \mathrm{Cl}^{-}\right.$, and $\left.\mathrm{SO}_{4}{ }^{2-}\right)$, AAS (Atomic Absorption Spectrometry) (Ca, Mg, Na, $\mathrm{K})$ and ICP-OES (Inductively Coupled Plasma Optical Emission Spectroscopy (Fe, Mn, Co, Cu, Ni, Zn). 


\section{RESULTS}

\section{Mineralogy and micromorphology of concretions}

The XRPD data show the presence of goethite in all samples with different degree of crystallinity testified by the sharp broadening of some characteristic peaks. The different spectra show an increase in crystallinity from ST to DRP and VEL to STG samples (Fig. 5).

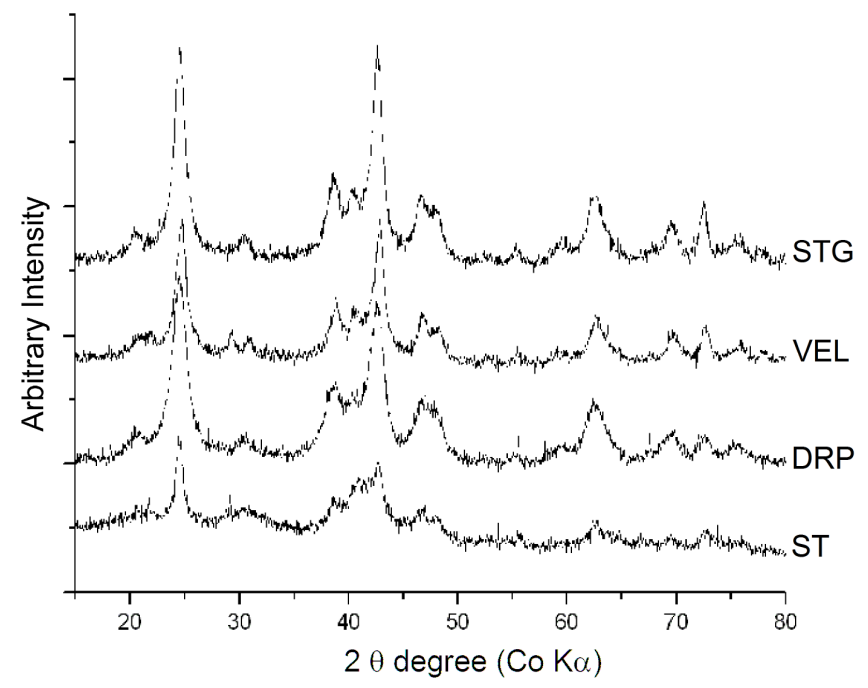

Fig. 5. XRPD patterns of stalactite (ST), stalagmite (STG), drapery (DRP and VEL) samples.

The stalagmite STG is composed of a big hollow core (Fig. 4a) and shows a submillimetric layering of goethite $\mathrm{FeO}(\mathrm{OH})$ marked by an alternation of fine-grained materials of the same composition. SEM images (Fig. 6) also show that the stalagmite is composed of two different layers. Layer 1 is characterized by vermicular goethite with evident flow structures. Layer 2 is more dense and massive than layer 1 and it seems to be formed by more compact aggregates of the same vermicular goethite. EDS analyses evidence a similar chemical composition of the two layers, that are almost exclusively composed of $\mathrm{Fe}$ with minor $\mathrm{S}, \mathrm{Si}$ and $\mathrm{Al}$, except for the higher levels of $\mathrm{Zn}$ in layer 1 and $\mathrm{Cu}$ in layer 2 .

Microtextural studies using scanning electronic microscopy performed on ST, DRP and VEL thin sections show a strong morphological difference between the recognized types.

The stalactite ST is characterized by a concentric layering, centred along a hollow core (Fig. 7a, b). The layering is composed of the alternation of thick (up to $200 \mu \mathrm{m}$ ) and very thin (up to few $\mu \mathrm{m}$ ) layers separated by voids. The thick layers show massive areas with mud cracks in the central parts and fibrous radiating areas toward the outer rims (Fig. 7c). The thin layers evidence a massive base from which botryoidal to mammillary textures develop (Fig. 7d). EDS analyses show similar chemical composition with respect to the other minothems except for the constant enrichment in $\mathrm{Cu}, \mathrm{Zn}$, and Ni (Table 1).
The sample DRP is characterized by an elliptical hollow feeding tube (Fig. 8a) surrounded by layering marked by a rhythmic alternation of massive micrometric goethite layers and empty layers. Between each layer botryoidal to mammillary goethite develops from the massive toward the empty layer (Fig. $8 \mathrm{~b}$ and c). EDS analyses evidence the same chemical features observed in the thin layers of stalactites (ST).

The sample VEL is composed of an alternation of two distinct zones (Fig. 9a). Zone 1 is characterized by thin layering of fibrous goethite with fibres radiating from the base of each layer (Fig. 9b). Unlike the previous type, the core is rarely empty and the surrounding layers show massive to irregular filling with botryoidal textures. Zone 2 is characterized by aggregates of subspheroidal goethite forming compact mosaic textures (Fig. 9c). Both zones have chemical composition very similar to the stalagmite STG except for the presence of $\mathrm{Ni}$ enrichment and for the absence of $\mathrm{Zn}$ (Table 1).

In order to understand the presence of voids among the layers of the studied minothems, all samples have been observed by putting fragments on stub sample holders. SEM images (Fig. 10) show that between the botryoidal aggregates of goethite, both ultrathin layers (Fig. 10b) and microbiological shapes (Fig. $10 \mathrm{c}$ and d) are present. These microbial components appear to be mainly composed of bacteria, spores and probably fungi in the form of filaments, microspheres and biofilm.

\section{Mud and colloidal precipitates of drip waters}

The XRPD results of muds display the presence of well crystalline goethite in all the samples (Fig. 11a). The solid fraction from drip waters was characterized
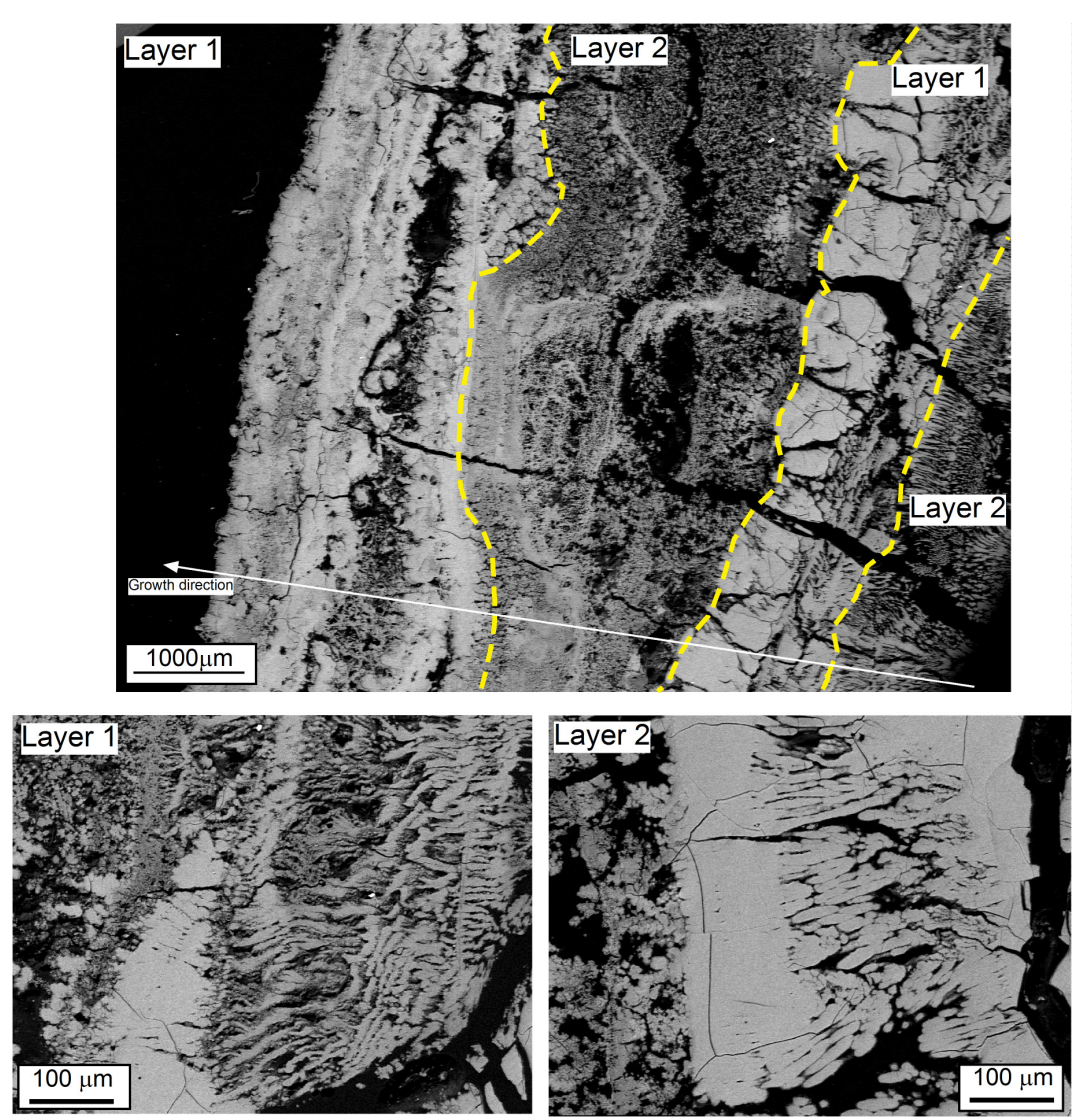

Fig. 6. SEM-BSE image of a stalagmite (STG) section in which different layer types (1 and 2) were distinguished. 

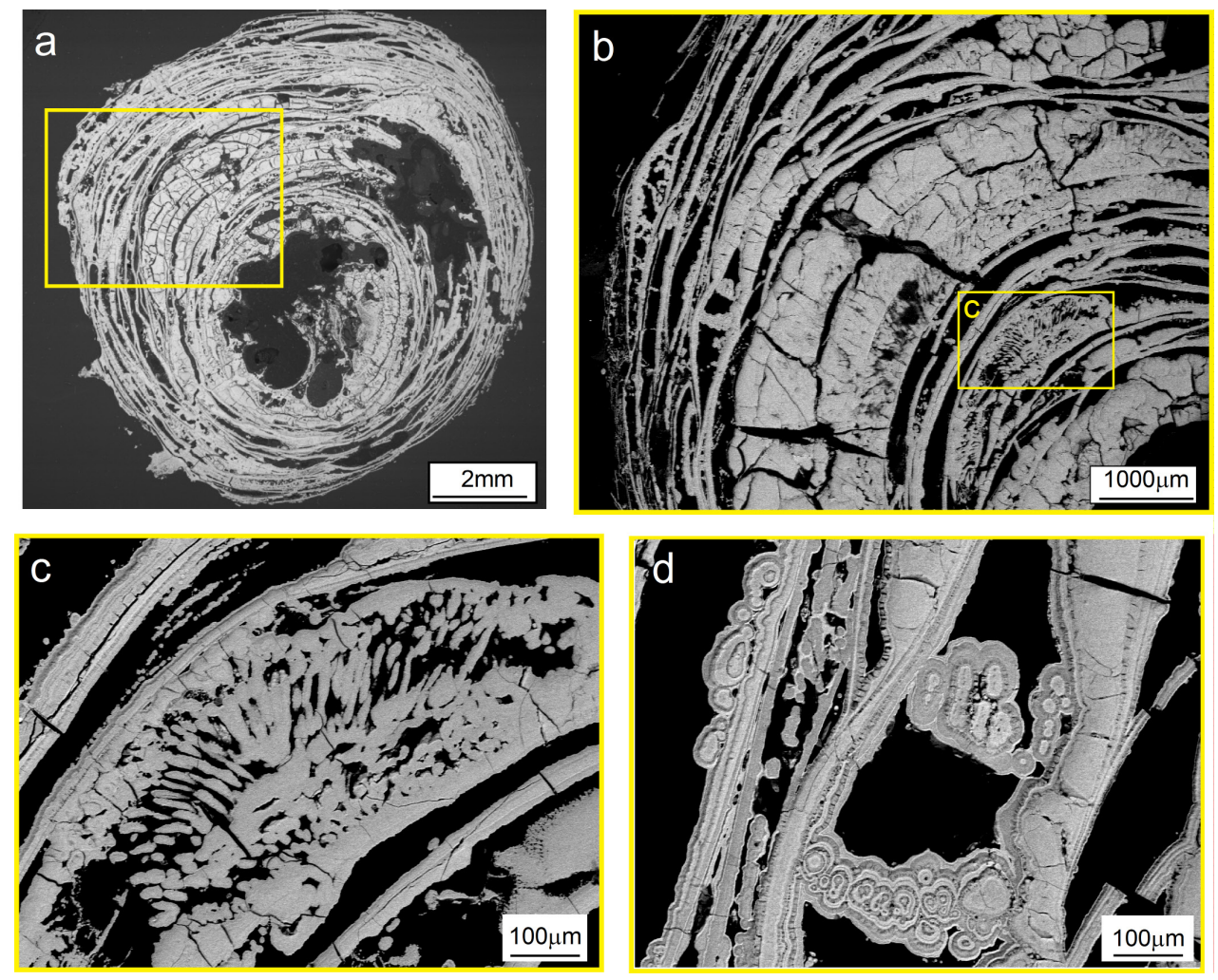

Fig. 7. SEM-BSE image of representative stalactite ST a) cross-section; b) alternation of thick and thin layers separated by empty zones; c) thick layers with fibrous radiating areas; d) thin layers with botryoidal to mammillary textures.

Table 1. Bulk chemical composition of representative samples of the different samples and of muds from the S. Barbara tunnel (LOI: Loss On Ignition).

\begin{tabular}{|l|c|c|c|c|c|c|}
\cline { 2 - 7 } \multicolumn{1}{c|}{} & Stalagmite & VEL & DRP & ST & $\begin{array}{c}\text { ST } \\
\text { soda straw }\end{array}$ & MudS \\
\hline $\mathrm{SiO}_{2}(\mathrm{wt} \%)$ & 0.43 & 1.02 & 0.57 & 2.04 & 5.51 & 1.41 \\
\hline $\mathrm{Al}_{2} \mathrm{O}_{3}$ & 0.03 & 1.00 & 0.19 & 0.65 & 1.30 & 0.80 \\
\hline $\mathrm{Fe}_{2} \mathrm{O}_{3}$ & 69.2 & 66.07 & 73.61 & 68.06 & 63.69 & 73.56 \\
\hline $\mathrm{MgO}$ & 0.01 & 0.01 & 0.01 & 0.04 & 0.32 & 0.07 \\
\hline $\mathrm{CaO}$ & 0.02 & 0.01 & 0.01 & 0.07 & 0.34 & 0.03 \\
\hline $\mathrm{Na}_{2} \mathrm{O}$ & 0.01 & 0.01 & 0.01 & 0.01 & 0.01 & 0.01 \\
\hline $\mathrm{K}_{2} \mathrm{O}$ & 0.01 & 0.01 & 0.01 & 0.01 & 0.01 & 0.01 \\
\hline $\mathrm{TiO} \mathrm{O}_{2}$ & 0.01 & 0.01 & 0.01 & 0.01 & 0.01 & 0.01 \\
\hline $\mathrm{P}_{2} \mathrm{O}_{5}$ & 0.09 & 1.36 & 0.20 & 0.37 & 0.07 & 0.10 \\
\hline $\mathrm{MnO}$ & 0.01 & 0.01 & 0.01 & 0.04 & 0.11 & 0.03 \\
\hline $\mathrm{LOI} 950$ & 20.24 & 24.22 & 21.92 & 22.23 & 22.77 & 25.47 \\
\hline $\mathrm{Ni}(\mathrm{mg} / \mathrm{kg})$ & 0.2 & 3 & 0.7 & 44.7 & 180 & 15.1 \\
\hline $\mathrm{Cu}$ & 475.2 & 4657 & 5401 & 6075 & 5215 & 7825 \\
\hline $\mathrm{Zn}$ & 319 & 218 & 91 & 1357 & 2676 & 363 \\
\hline $\mathrm{Co}$ & 3.1 & 2 & 1.1 & 42.4 & 140.1 & 18.6 \\
\hline $\mathrm{V}$ & 8 & 512 & 228 & 201 & 28 & 63 \\
\hline $\mathrm{Cr}$ & 30 & 75 & 30 & 30 & 30 & 30 \\
\hline $\mathrm{As}$ & 1.6 & 4.6 & 1.2 & 3.5 & 5.4 & 0.5 \\
\hline $\mathrm{Cd}$ & 0.1 & 0.3 & 0.1 & 5.4 & 17.8 & 2 \\
\hline & & & & & & \\
\hline
\end{tabular}



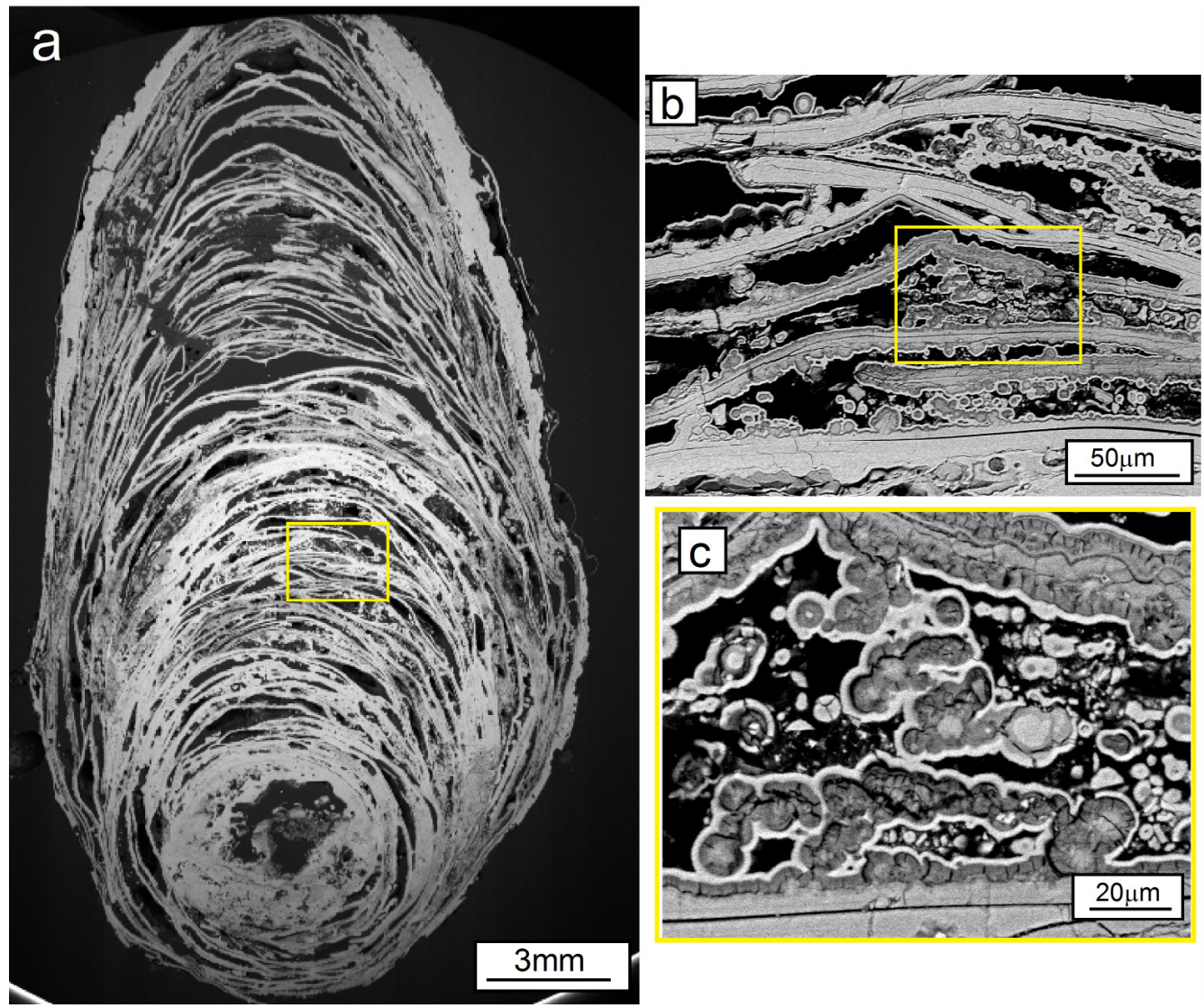

Fig. 8. SEM-BSE image of the drapery sample DRP a) cross-section; b) and c) layer of botryoidal to mammillary goethite.
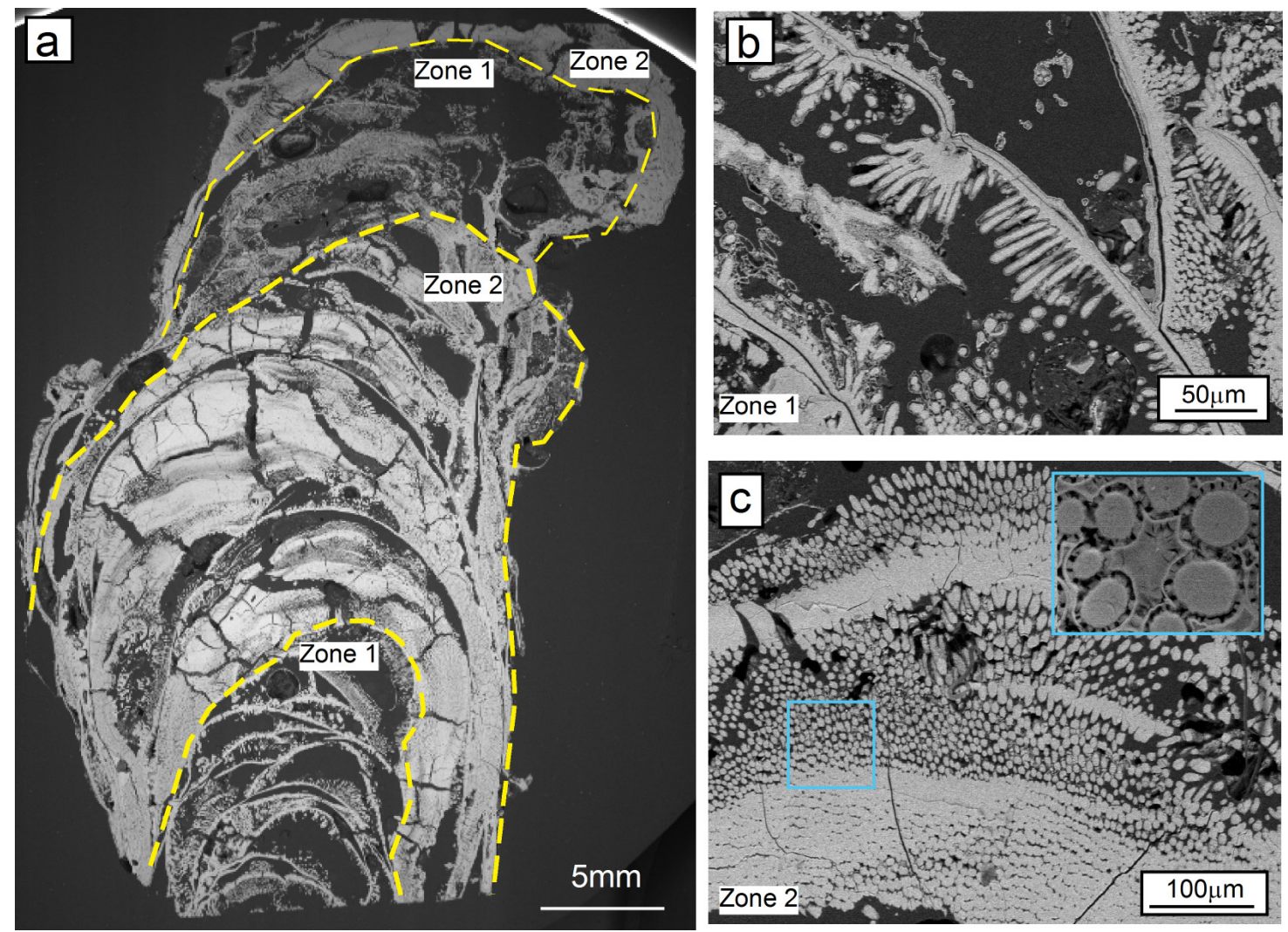

Fig. 9. SEM-BSE image of the drapery sample VEL a) cross-section with an alternation of two distinct zones; b) thin layering of fibrous goethite c) mosaic texture with aggregates of sub-spheroidal goethite. 
by the presence of colloidal precipitates composed of ferrihydrite nanoparticles (Fig. 11b) and amorphous phases, which are the stable phases according to thermodynamic calculations (see discussion).

\section{Bulk chemistry}

The bulk chemistry of minothem samples and the muds is reported in Table 1 . As concerns the major elements, iron is the most abundant element in all the minothem samples (Table 1) ranging from 63.69 to $73.61 \mathrm{wt} \% \mathrm{Fe}_{2} \mathrm{O}_{3}$. The $\mathrm{ST}$ soda straw contains impurities as testified by the higher concentrations of elements like $\mathrm{SiO}_{2}, \mathrm{Al}_{2} \mathrm{O}_{3}, \mathrm{MgO}$, and $\mathrm{CaO}$. $\mathrm{SiO}_{2}$ and $\mathrm{Al}_{2} \mathrm{O}_{3}$ were detected also in the VELA sample. It is interesting to note the high $\mathrm{P}_{2} \mathrm{O}_{5}$ concentration recorded in VEL sample (1.36 wt\% $\left.\mathrm{P}_{2} \mathrm{O}_{5}\right)$, but also in all the other samples. Compared to the other samples, the mud is high in iron and has traces of all the other major elements. All the other elements have a large variability, although samples ST and ST soda straw show the highest metal concentration. In particular the ST soda straw has the highest concentration of $\mathrm{Ni}, \mathrm{Zn}, \mathrm{Co}, \mathrm{Cd}$ and high $\mathrm{Cu}$ whereas $\mathrm{ST}$ records the highest $\mathrm{Cu}$ concentration reaching $6075 \mathrm{mg} / \mathrm{kg}$. Copper is also high in the VEL and DRP samples, and one order of magnitude lower in STG. It is worth
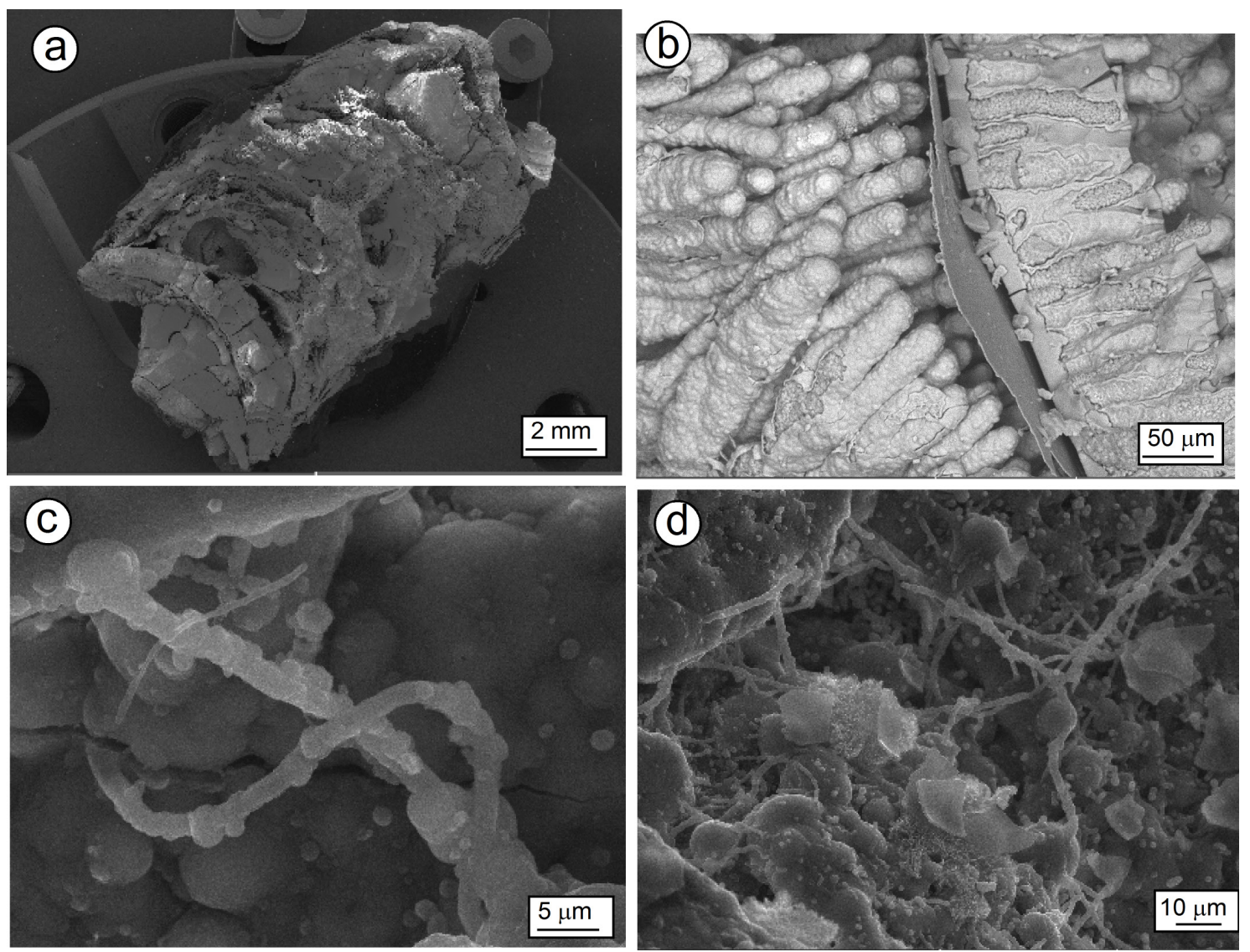

Fig. 10. SEM images of minothems (a) showing thin layers between botryoidal goethite aggregates (b), and microbiological structures (c and d).
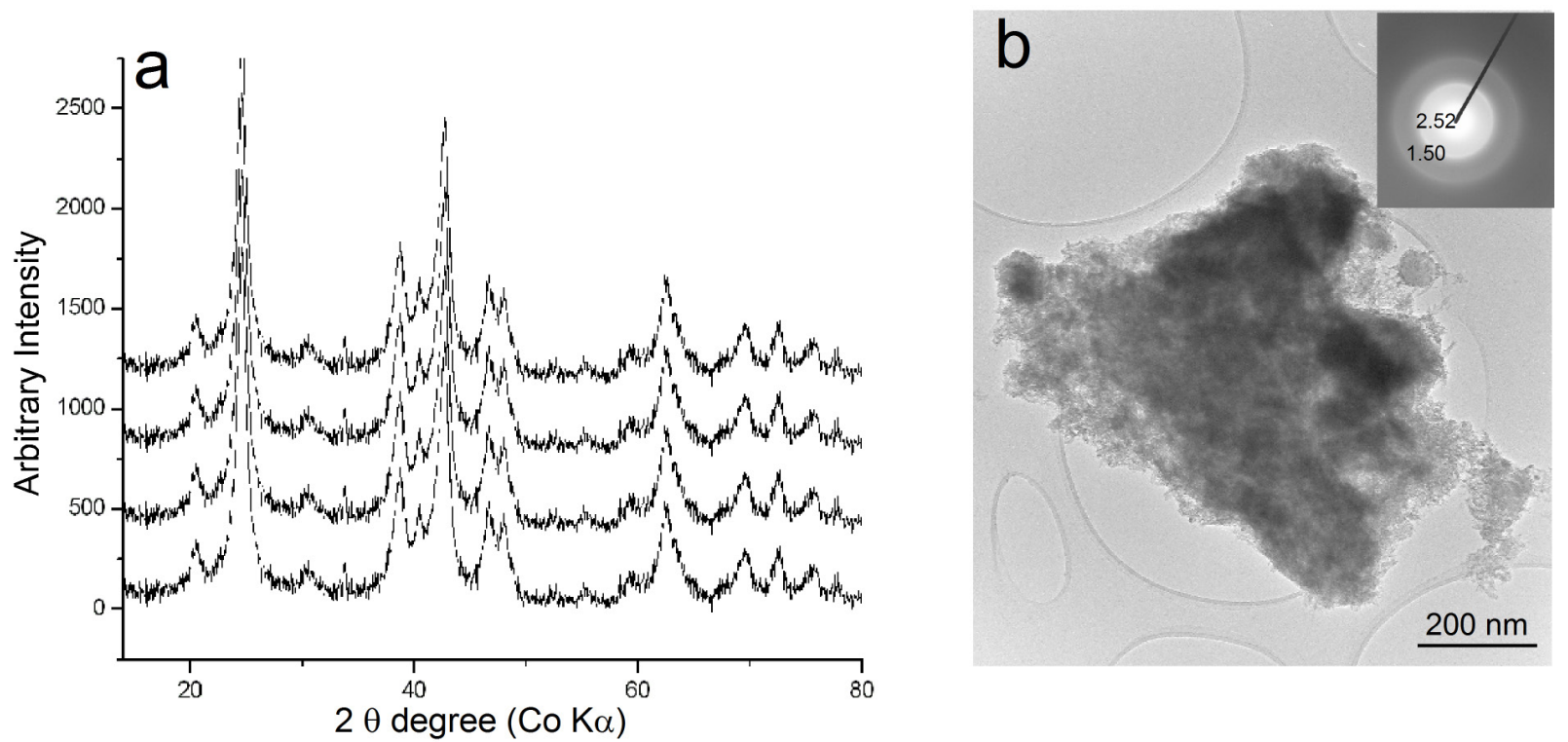

Fig. 11. a) XRPD spectra of mud samples and b) TEM image and in the inset SAED of ferrihydrite 2-line. 
mentioning that these three last minothems show the lowest concentrations of the considered trace elements, with the exception of $\mathrm{V}$.

\section{Water and drip water chemistry}

Drip samples are mildly acidic $(5.8<\mathrm{pH}<6.1)$ showing intermediate conductivity $(2210-2640 \mu \mathrm{S} / \mathrm{cm})$ and are dominated by magnesium and sulfate, with low concentration of dissolved iron but still containing traces of $\mathrm{Cu}, \mathrm{Ni}$, and $\mathrm{Zn}$ (Table 2). Waters draining the tunnel and in contact with mud samples have comparable $\mathrm{pH}$, with higher electrical conductivity. They are depleted in iron but contain $\mathrm{Cu}, \mathrm{Ni}$, and $\mathrm{Zn}$ to appreciable levels (Table 2). Concerning the $\mathrm{SO}_{4}{ }^{2-}$ content, the water associated with muds shows higher values (1400-1800 mg/l) compared to drip water (about $800 \mathrm{mg} / 1$ ). In order to identify the solid phases controlling the chemistry of the AMD solutions, Eh-pH stability calculations (Fig. 12) were performed with the application "act2" of the software "The Geochemist's Workbench" (version 7.0; Bethke \& Yeakel, 2014), using the LLNL Thermodynamic Database (Wolery, 1992) supplemented by schwertmannite data from Bigham et al. (1996), Yu et al. (1999), and Kawano and Tomita (2001), ferrihydrite data from Majzlan et al. (2004), and jarosite data from Bigham et al. (1996).

Table 2. Chemical composition of mine and drip waters (MW and DW) sampled in 2010.

\begin{tabular}{|l|c|c|c|c|c|c|c|c|c|c|}
\hline Sample & MW 1 & MW 2 & MW 3 & MW 4 & MW1 & MW2 & MW3 & MW4 & DW1 & DW2 \\
\hline Date & June & June & June & June & July & July & July & July & June & July \\
\hline $\mathrm{T}\left({ }^{\circ} \mathrm{C}\right)$ & 15.7 & 17.4 & 18.3 & 17.8 & 18.2 & 17.5 & 21 & 21.9 & 16.5 & 20.4 \\
\hline $\mathrm{pH}$ & 6.1 & 5.9 & 5.9 & 5.9 & 6.8 & 6.6 & 6.5 & 5.8 & 6.8 & 6.0 \\
\hline $\mathrm{Eh}(\mathrm{mV})$ & 450 & 423 & 360 & 368 & 365 & 442 & 361 & 446 & 228 & 457 \\
\hline $\mathrm{EC}(\mu \mathrm{S} / \mathrm{cm})$ & 2210 & 2290 & 2250 & 2640 & 2310 & 2210 & 2230 & 2200 & 860 & 1510 \\
\hline $\mathrm{Ca}(\mathrm{mg} / \mathrm{L})$ & 153.6 & 183.9 & 200.0 & 198.8 & 306.3 & 184.2 & 221.0 & 227.6 & 81.6 & 81.1 \\
\hline $\mathrm{Mg}$ & 225.6 & 228.5 & 225.8 & 240.3 & 224.2 & 241.7 & 217.4 & 229.8 & 162.6 & 143.9 \\
\hline $\mathrm{Na}$ & 9.2 & 8.6 & 8.8 & 8.8 & 9.0 & 9.7 & 8.9 & 8.9 & 10.3 & 11.0 \\
\hline $\mathrm{K}$ & 4.4 & 5.0 & 5.0 & 4.6 & 6.1 & 4.8 & 4.4 & 4.6 & 0.7 & 1.0 \\
\hline $\mathrm{Fe}$ & 0.2 & 0.4 & 0.1 & 1.0 & 0.5 & 0.3 & 0.1 & 0.5 & $<0.05$ & 0.5 \\
\hline $\mathrm{Mn}$ & 2.5 & 2.5 & 2.2 & 2.8 & 2.2 & 2.0 & 1.9 & 2.1 & 0.3 & 0.8 \\
\hline $\mathrm{Co}$ & 0.3 & 0.3 & 0.2 & 0.3 & 0.3 & 0.3 & 0.2 & 0.3 & $<0.05$ & 0.1 \\
\hline $\mathrm{Cu}$ & 6.7 & 6.8 & 4.7 & 8.3 & 7.3 & 7.1 & 5.6 & 7.6 & 0.2 & 2.7 \\
\hline $\mathrm{Ni}$ & 2.9 & 2.5 & 2.1 & 2.9 & 2.6 & 2.7 & 3.0 & 3.0 & 0.5 & 0.6 \\
\hline $\mathrm{Zn}$ & 4.1 & 3.9 & 3.3 & 4.7 & 3.7 & 3.6 & 3.2 & 3.7 & 1.3 & 2.8 \\
\hline $\mathrm{HCO}{ }_{3}$ & 42.7 & 18.3 & 24.4 & 36.6 & 30.5 & 30.5 & 27.5 & 21.4 & 30.5 & 21.4 \\
\hline $\mathrm{F}$ & 0.7 & 0.3 & 0.4 & 0.8 & 0.3 & 0.3 & 0.9 & 1.1 & 0.1 & 0.3 \\
\hline $\mathrm{Cl}^{\mid}$ & 4.8 & 11.1 & 4.0 & 5.8 & 4.4 & 3.0 & 4.7 & 4.3 & 29.0 & 7.2 \\
\hline $\mathrm{SO}_{4}$ & 1553 & 1547 & 1525 & 1831 & 1430 & 1444 & 1489 & 1492 & 822 & 808 \\
\hline
\end{tabular}

\section{DISCUSSION}

Among all the mine drainages of the area, the Santa Barbara level shows a weakly acidic drainage (Dinelli et al., 2001; Dinelli \& Tateo, 2002; Marini et al., 2003; Accornero et al., 2005; Marescotti et al., 2012) (Fig. 13a). Besides Santa Barbara, only the closed Margherita adit has water with a systematically higher pH (Carbone et al., 2013). The water chemistry is also different, shows a slightly higher $\mathrm{Mg}^{2+} / \mathrm{SO}_{4}{ }^{2-}$ molar ratio, compared to the other waters (Fig. 13b). This suggests a water chemistry evolution involving interaction with the local serpentinites (in which calcite veins occur), which leads to buffering of the initial acidity generated by sulfide oxidation (testified by $\mathrm{SO}_{4}{ }^{2-}$ ) and promotes the precipitation of iron minerals.

Compared to data published on muds from other sites in the area (Dinelli et al., 2001; Marescotti et al., 2012; Carbone et al., 2012) those from Santa Barbara are characterized by a much higher $\mathrm{Cu}$ and $\mathrm{Zn}$ content, a feature that is shared also with many of the minothem samples. In other sites in the area copper-rich precipitates were observed in water with pH around 7 (Dinelli et al., 1998; Dinelli \& Tateo, 2002). The mine area, as well as the Santa Barbara
Adit, actually has a pH close to 6 , which could also cause an increase in copper adsorption onto goethite with or without the presence of organic substances, as testified by several authors (e.g., Kooner, 1993; Christophi \& Axe, 2000; Buerge-Weirich et al., 2002; Ponthieu et al., 2006).

The Santa Barbara level of Libiola Mine hosts a wide variety of minothems very different in form and color from classic speleothems. In this setting, stalactites, stalagmites and drapery-like stalactites of goethite were found. In particular all morphologies of typical carbonate speleothems were recognized. Three main types of growth have been identified: (1) classical stalactite (ST) type that displays mostly cylindrical shapes with a hollow feeding channel; their axes are vertical, indicating that the deposition was influenced by gravity and that no tilting occurred since their formation. This type was characterized by a low crystalline goethite (Fig. 5) which forms massive layers and thin layers with botryoidal texture and contains some potential toxic elements such as $\mathrm{Ni}$, $\mathrm{Cu}, \mathrm{Zn}$, and As. (2) Drapery (DRP) type related to deposition along the margin of a pendant drop and displaying an elliptical hollow core. The goethite is more crystalline than that in the true stalactite (Fig. 5) and the botryoidal growth of goethite is very 


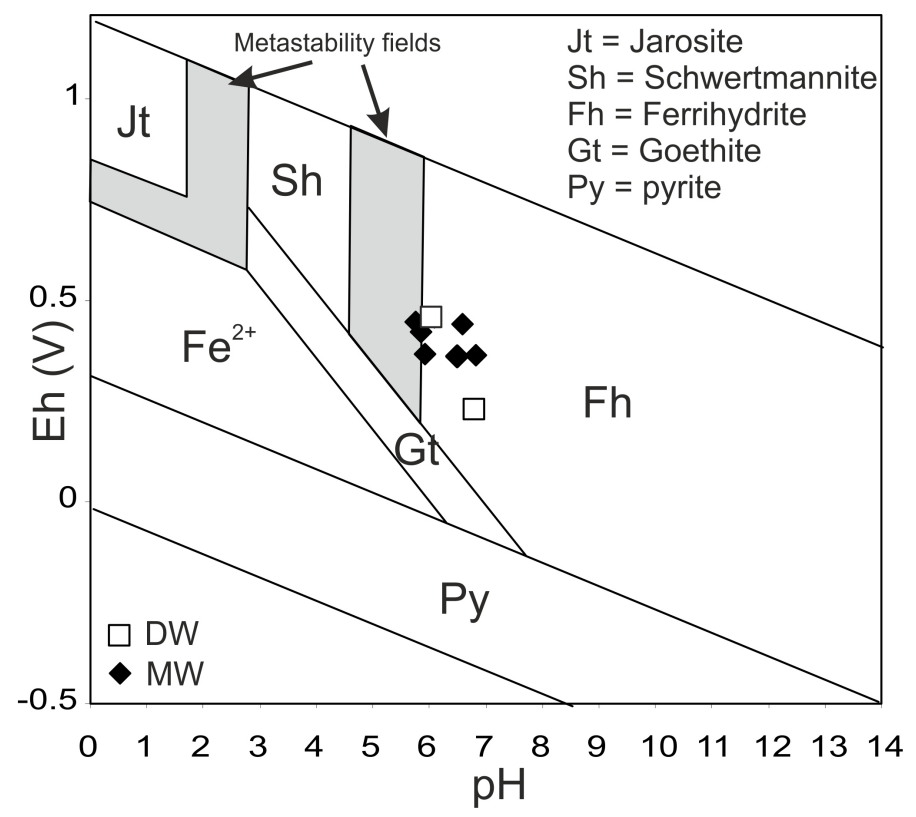

Fig. 12. Eh-pH diagram for the sampled waters. Eh: oxidation-reduction potential; $\mathrm{pH}$ : acidity. The water samples fall in the ferrihydrite stability fields. Methodological details are reported in the text. MW and DW are mine water and drip water samples.

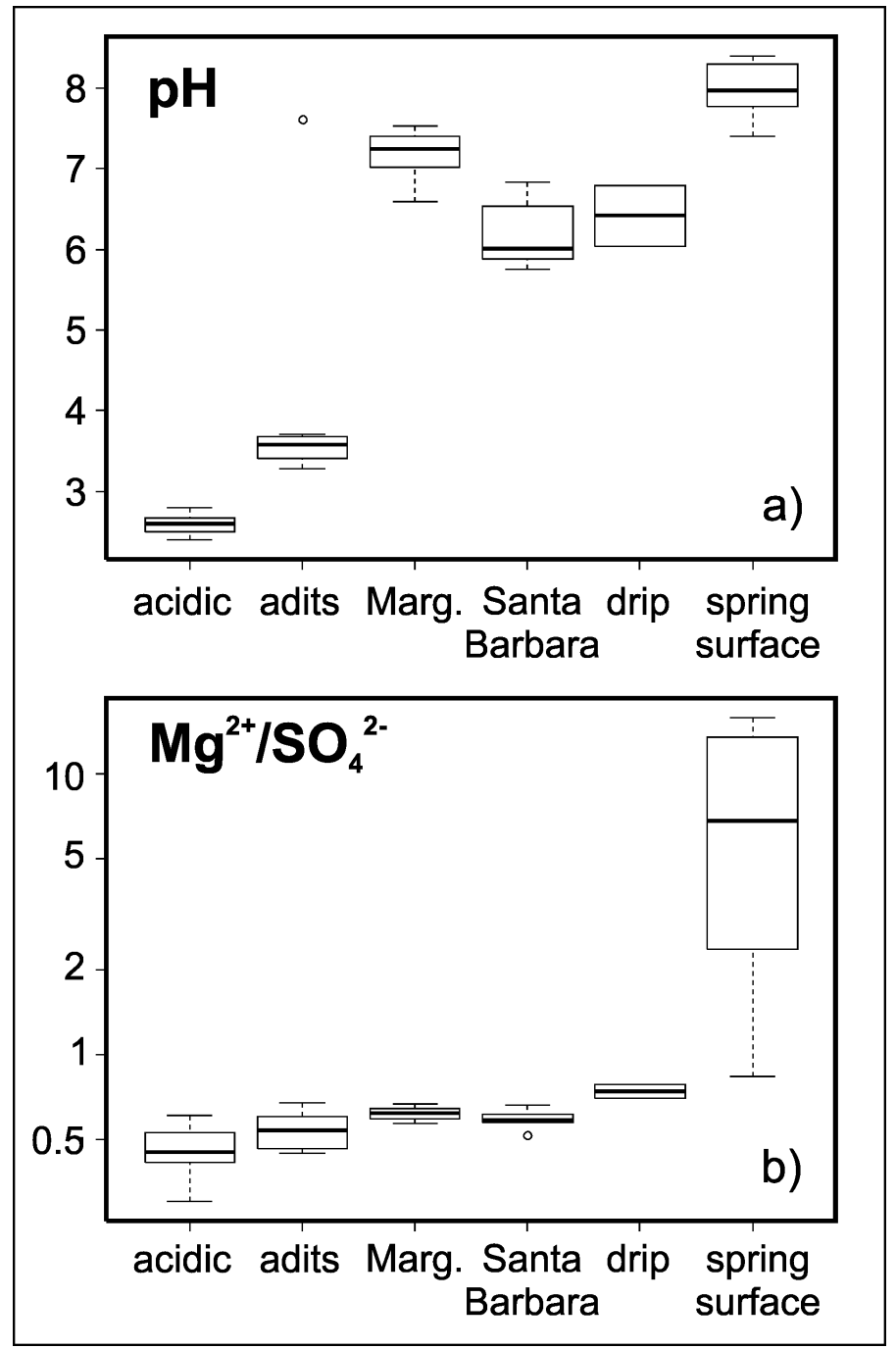

Fig. 13. Comparison of $\mathrm{pH}(\mathrm{a})$ and $\mathrm{Mg}^{2+} / \mathrm{SO}_{4}{ }^{2-}$ on a molar basis (b) of different types of waters flowing from adits and galleries in the Libiola mining area. Acidic: samples from Ida, Castagna, and Weirs; adits: samples from occasional water flow; Marg.: samples from Margherita tunnel; Santa Barbara: present work tunnel waters; drip: present work drip waters; spring-surface: spring and surface waters not affected by mine waters (data from Dinelli et al., 2001; Dinelli \& Tateo, 2002; Marini et al., 2003; Accornero et al., 2005; Marescotti et al., 2012). similar to that observed in the stalactite type. (3) The drapery (VEL) type is curved along its length because it formed along the flow path of droplets along the ceiling. Both drapery types were not present in the main tunnel and have only been found in the small lateral chamber. They are characterized by a more crystalline goethite than the others (almost all the peaks are present even if very broad, Fig. 5) with a vermicular and mammillary texture that tends to join and form massive and compact layers.

Stalagmites show a big hollow core with pancake morphologies and are characterized by wellcrystallized goethite testified also by the massive aggregation in the observed thin sections.

The increase in crystallinity from stalactite to draperies (Fig. 5) and the different micromorphologies of the different minothems seem to be related to an ageing of goethite nanocrystals: the stalactite types have a faster growth compared to drapery types. The stalagmites have also a slow growth, supported by their pan-cake morphologies (Allison, 1923). Moreover, the botryoidal character of goethite could indicate rapid crystallization from supersaturated drip solutions, whereas the coarser crystallinity of goethite in draperies and stalagmites implies slower growth through time.

The Eh-pH diagram of Fig. 12 shows that the physico-chemical conditions are consistent with the stability of ferrihydrite, which however tends to transform into goethite upon aging. Few of the mud waters plot close to the metastability field of schwertmannite. The diagram is based on equilibrium reactions that could actually be changed by bacterial reactions able to modify the predicted stable phase (Fig. 12). The drip waters from stalactites, present prevalently in the main tunnel, are characterized by the presence of colloidal precipitates composed of ferrihydrite nanoparticles (Fig. 11b) and amorphous phases, which are the stable phases according to thermodynamic calculations. The presence of these minerals could be related to a possible "precursor" phase to the goethite formation (Schwertmann et al., 1999) that due to its high surface reactivity tends to retain into the structure some potentially toxic elements. In fact, there is a clear distinction between the stalagmite, the stalactites, and the draperies (Table 1) in terms of chemical composition. All stalactites have a homogeneous composition concerning the major elements showing a strong enrichment of $\mathrm{Fe}$ and subordinate amounts of $\mathrm{Si}, \mathrm{Al}$, and $\mathrm{P}$, whereas stalagmite samples contain only $\mathrm{Fe}$ as major element. Concerning minor and trace elements (Table 1), $\mathrm{Cu}$ is high in all the samples (although less in stalagmites) whereas only the soda-straw stalactites record a strong enrichment in $\mathrm{Zn}, \mathrm{Co}$, and $\mathrm{Cd}$. These results suggest that poor and low crystalline goethite tends to retain into its structure more chemical elements than the well-crystallized one.

All these minothems are characterized by a layering around a hollow core, except for the VEL drapery; each layer is composed of a film of different thickness probably due to variable growth rates. The presence of the voids among the layering could be related 
either to the presence of colloidal and/or amorphous phases that tend to disappear when transformation into goethite takes place or to the presence of organic matter (high concentrations of $\mathrm{P}_{2} \mathrm{O}_{5}$ in some samples) which also decays and leaves the voids. Some aspects of this work are still unclear concerning the role of bacteria or other microbiological forms in constructing these minothems (Fig. 10). This might not be negligible, since microbial mediation in speleothem formation is especially important in environments with high concentration of metals (Tisato et al., 2015). According to the observations of Spear et al. (2007), Florea et al. (2011), and Gherman et al. (2014) on comparable speleothems, the microbial population promotes and contributes to the mineral precipitation on the biofilms in Fe-rich speleothems.

\section{CONCLUSIONS}

Results from this study provide a detailed characterization of minothems formed in a particular environmental setting such as the Libiola Mine (eastern Liguria, Italy) in which $\mathrm{Cu}$-sulfides are oxidizing.

This study has identified numerous minothem forms, such as soda straws, stalactites, draperies, stalagmites, columns, flowstones, jellystones, snottites, gours, pearls, rafts, and helictites. The large amount of secondary iron and copper minerals discovered is due to the oxidation of $\mathrm{Fe}-\mathrm{Cu}$ sulfide minerals occurring in the surficial and underground mining area. The geochemical calculations are compatible with the mineralogical data: the presence of ferrihydrite is consistent with a possible precursor that however, tends to transform into goethite upon ageing. Goethite is the only mineral present in stalagmites, stalactites and draperies but its degree of crystallinity and the microtexture is quite different in each sample. This work demonstrates that there is an increase in crystallinity from stalactite to draperies to stalagmites and the passage from botryoidal form to massive aggregates indicates an ageing of goethite nanocrystals. The stalactite type samples have a faster growth compared to drapery types, while stalagmites grow more slowly. Further investigations are in progress in order to understand the role of microorganism in the minothem formation and the cause of the presence of voids between goethite layering. The occurrence of many different minothem forms, together with the extent of the weathering Fe-Cu sulfide developed on non-karst rocks make the Libiola Mine an important site for the study of minothems in acidic tunnels also for the possible implications to the mineralogical and biogeochemical study of extraterrestrial environments.

\section{ACKNOWLEDGMENTS}

We wish to thank the mine owner Arturo Corti for the permission and the participation to visit Santa Barbara level and for sampling. Moreover we wish to thank Christian Muzio and Stefano Camarda for having shared some minothem samples. This study was funded by MIUR - (Italian) Ministero
dell'Istruzione, dell'Università e della Ricerca (PRINCOFIN 2010-2011): "Minerals-Biosphere Interaction: Environmental and Health Consequences".

Bogdan P. Onac and three anonymous reviewers provided useful comments and welcome suggestions for improving the quality and content of this manuscript.

\section{REFERENCES}

Abbate E., Bortolotti V. \& Principi G., 1980 - Appennine Ophiolites: a peculiar oceanic crust. Ofioliti Special Issue "Thethian Ophiolites: 1, western area", 1: 59-96. Accornero M., Marini L., Ottonello G. \& Zuccolini M., 2005 - The fate of major constituents and chromium and other trace elements when acid waters from the derelict Libiola mine (Italy) are mixed with stream waters. Applied Geochemistry, 20: 1368-1380.

http://dx.doi.org/10.1016/j.apgeochem.2005.03.001

Allison V.C., 1923 - The growth of stalagmites and stalactites. Journal of Geology, 31 (2): 106-125. http://dx.doi.org/10.1086/622988

Ara D., Sanna L., Rossi A., Galli E. \& De Waele J., 2013 - Minerali secondari in ambiente sotterraneo: la miniera dell'Argentiera (Sardegna nord-occidentale). In: Cucchi F. \& Guidi P. (Eds.), Atti del XXI Congresso Nazionale di Speleologia "Diffusione delle conoscenze", Trieste: 290-295.

Arnold T., Baumann N., Krawczyk-Barsch E., Brockmann S., Zimmermann U., Jenk U. \& Weiß S., 2011 - Identification of the uranium speciation in an underground acid mine drainage environment. Geochimica et Cosmochimica Acta, 75: 2200-2212. http://dx.doi.org/10.1016/j.gca.2011.01.037

Baker A., Smith C.L., Jex C., Fairchild I.J., Genty D. \& Fuller L., 2008 - Annually laminated speleothems: a review. International Journal of Speleology, 37 (3): 193-206.

http://dx.doi.org/10.5038/1827-806X.37.3.4

Banfield J.F., Welch S.A., Zhang H., Thomsen Ebert T. \& Penn R.L., 2000 - Aggregation-based crystal growth and microstructure development in natural iron oxyhydroxide biomineralization products. Science, 289: 751-754.

http://dx.doi.org/10.1126/science.289.5480.751

Barton H.A. \& Northup D.E., 2007 - Geomicrobiology in cave environments: past, current and future perspectives. Journal of Cave and Karst Studies, 69: 163-178.

Baskar S., Baskar R., Lee N., Kaushik A. \& Theophilus P.K., 2008 - Precipitation of iron in microbial mats of the spring waters of Borra Caves, Vishakapatnam, India: some geomicrobiological aspects. Environmental Geology, 56: 237-243. http://dx.doi.org/10.1007/s00254-007-1159-y

Bethke C.M. \& Yeakel S., 2014, The Geochemist's Workbench. Release 7.0. Reference Manual. University of Illinois.

Bigham J.M., Schwertmann U., Traina S.J., Winland R.L. $\&$ Wolf M., 1996 - Schwertmannite and the chemical modeling of iron in acid sulfate waters. Geochimica et Cosmochimica Acta, 60: 2111-2121. http://dx.doi.org/10.1016/0016-7037(96)00091-9

Buerge-Weirich D., Hari R., Xue H., Behra P. \& Sigg L., 2002 - Adsorption of $\mathrm{Cu}, \mathrm{Cd}$, and $\mathrm{Ni}$ on goethite in the presence of natural groundwaterligands. Environmental Science and Technology, 36 (3): 328-336. http://dx.doi.org/10.1021/es010892i

Cabała J. \& Bzowska G., 2008 - Sulphate speleothems in Pomorzany $\mathrm{Zn}-\mathrm{Pb}$ ore mine, southern Poland. Kras $\mathrm{i}$ speleologia, 12 (21): 59-76. 
Campbell W.R. \& Barton P.B., 1996 - Occurrence and significance of stalactites within the epithermal deposits at Creede, Colorado. The Canadian Mineralogist, 34: 905-930.

Carbone C., Di Benedetto F., Marescotti P., Martinelli A., Sangregorio C., Cipriani C., Lucchetti G. \& Romanelli M., 2005 - Genetic evolution of nanocrystalline Fe oxide and oxyhydroxide assemblages from the Libiola Mine (eastern Liguria, Italy): structural and microstructural investigations. European Journal of Mineralogy, 17: $785-795$.

http://dx.doi.org/10.1127/0935-1221/2005/0017-0785

Carbone C., Marescotti P., Lucchetti G., Martinelli A., Basso R. \& Cauzid J., 2012 - Migration of selected elements of environmental concern from unaltered pyrite-rich mineralizations to Fe-rich alteration crusts. Journal of Geochemical Exploration, 114: 109-117. http://dx.doi.org/10.1016/j.gexplo.2012.01.003

Carbone C., Dinelli E., Marescotti P., Gasparotto G. \& Lucchetti G., 2013 - The role of AMD secondary minerals in controlling environmental pollution: indications from bulk leaching tests. Journal of Geochemical Explorations, 132: 188-200.

http://dx.doi.org/10.1016/j.gexplo.2013.07.001

Christophi C.A. \& Axe L., 2000 - Competition of $\mathrm{Cd}, \mathrm{Cu}$, and $\mathrm{Pb}$ adsorption on goethite. Journal of Environmental Engineering, 126: 66-74.

http://dx.doi.org/10.1061/(ASCE)0733-9372(2000) 126:1(66)

Daza R. \& Bustillo M.A., 2015 - Allophanic and ferricroot-associated stalactites: biomineralization induced by microbial activity (Galeria da Queimada lava tube, Terceira, Azores). Geological Magazine, 152 (3): 504-520. http://dx.doi.org/10.1017/S0016756814000491

de los Rìos A., Bustillo M.A., Ascaso C. \& Carvalho M.R., 2011 - Bioconstructions in ochreous speleothems from lava tubes on Terceira Island (Azores). Sedimentary Geology, 236: 117-128.

http://dx.doi.org/10.1016/j.sedgeo.2010.12.012

Dinelli E. \& Tateo F., 2002 - Different types of fine grained sediments associated with acid mine drainage in the Libiola $\mathrm{Fe}-\mathrm{Cu}$ mine area (Ligurian Apennines, Italy). Applied Geochemistry, 17: 1081-1092.

http://dx.doi.org/10.1016/S0883-2927(02)00009-4

Dinelli E., Morandi N. \& Tateo F., 1998 - Fine-grained weathering products in waste disposal from two sulphide mines in the northern Apennines, Italy. Clay Minerals, 33: 423-433.

http://dx.doi.org/10.1180/000985598545723

Dinelli E., Lucchini F., Fabbri M. \& Cortecci G., 2001 Metal distribution and environmental problems related to sulfide oxidation in the Libiola copper mine area (Ligurian Apennines, Italy). Journal of Geochemical Exploration, 74: 141-152. http://dx.doi.org/10.1016/S0375-6742(01)00180-7

Fairchild I.J. \& Baker A., 2012 - Speleothem science: form process to past environments. John Wiley \& Sons. Oxford, UK. http:/ / dx.doi.org/10.1002/9781444361094

Florea L.J., Noe-Stinson C.L., Brewer J., Fowler R., Kearns J.B. \& Greco A.M., 2011 - Iron oxide and calcite associated with Leptothrix $s p$. biofilms within an estavelle in the upper Floridan aquifer. International Journal of Speleology, 40 (2): 205-219.

http:/ /dx.doi.org/10.5038/1827-806X.40.2.12

Frierdich A.J. \& Catalano J.G., 2012 - Distribution and speciation of trace elements in iron and manganese oxide cave deposits. Geochimica et Cosmochimica Acta, 91: 240-253.

http://dx.doi.org/10.1016/j.gca.2012.05.032
Frierdich A.J., Hasenmueller E.A. \& Catalano J.G., 2011 - Composition and structure of nanocrystalline Fe and Mn oxides cave deposits: implication for trace element mobility in karst systems. Chemical Geology, 284: 82-96. http://dx.doi.org/10.1016/j.chemgeo.2011.02.009

Galli M. \& Penco A.M., 1996 - Le miniere di rame e di manganese della Liguria Orientale. Atti dell'Accad. Ligure di Sci. Lett., 53: 215-247

Gàzquez F., Rull F., Calaforra J. M., Venegas G., Manrique J. A., Sanz A., Medina J., Català-Espì A., Sansano A., Navarro R., Forti P., De Waele J. \& Martinez-Frìas J., 2014 - Caracterización mineralógica y geoquímica de minerales hidratados de ambientes subterráneos: implicaciones para la exploración planetaria. Estudios Geologicos, 70 (2): e009.

http://dx.doi.org/10.3989/egeol.41688.314

Gherman V.D., Boboescu I.Z., Pap B., Kondorosi E., Gherman G. \& Maróti G., 2014 - An Acidophilic bacterial-archaeal-fungal ecosystem linked to formation of ferruginous crusts and stalactites. Geomicrobiology Journal, 31 (5): 407-418.

http://dx.doi.org/10.1080/01490451.2013.836580

Hill C.A. \& Forti P., 1997 - Cave minerals of the World. National Speleological Society, Huntsville, Alabama, USA, $463 \mathrm{p}$.

Hose L. D. \& Pisarowicz J. A., 1999 - Cueva de Villa Luz, Tabasco, Mexico: reconnaissance study of an active sulfur spring cave and ecosystem. Journal of Cave and Karst Studies, 61 (1): 13-21.

Jamieson H.E., Robinson C., Alpers C.N., Nordstrom D.K., Poustovetou A. \& Lowers H.A., 2005 - The composition of coexisting jarosite-group mineral and water from Richmond mine, Iron Mountain, California. The Canadian Mineralogist, 43: 1225-1242. http://dx.doi.org/10.2113/gscanmin.43.4.1225

Jebrak M., Marcoux E. \& Fontaine D., 1996 Hydrothermal silica-gold stalactites formed by colloidal deposition in the Citrotan epithermal deposit, Indonesia. The Canadian Mineralogist, 34: 931-938.

Jones D., Schaperdoth I. \& Macalady J., 2010 Metagenomics reveal structure and function of extremely acidic sulfur oxidizing cave wall biofilms. Geochimica et Cosmochimica Acta, 74 (12): 479-479.

Kasama T. \& Murakami T., 2001 - The effect of microorganisms on $\mathrm{Fe}$ precipitation rates at neutral $\mathrm{pH}$. Chemical Geology, 180: 117-128.

http://dx.doi.org/10.1016/S0009-2541(01)00309-6

Kawano M. \& Tomita K., 2001 - Geochemical modeling of bacterially induced mineralization of schwertmannite and jarosite in sulfuric acid spring water. American Mineralogist, 86: 1156-1165. http://dx.doi.org/10.2138/am-2001-1005

Kooner Z.S., 1993 - Comparative study of adsorption behavior of copper, lead, and zinc onto goethite in aqueous systems. Environmental Geology, 21: 242-250. http://dx.doi.org/10.1007/BF00775914

Majzlan J., Navrotsky A. \& Schwertmann U., 2004 Thermodynamics of iron oxides: Part III. Enthalpies of formation and stability of ferrihydrite $\left(\mathrm{Fe}(\mathrm{OH})_{3}\right)$, schwertmannite $\left(\mathrm{FeO}(\mathrm{OH})_{3} /{ }_{4}\left(\mathrm{SO}_{4}\right)_{1 / 8}\right)$, and $\alpha-\mathrm{Fe}_{2} \mathrm{O}_{3}$. Geochimica et Cosmochimica Acta, 68: 1049-1059. http://dx.doi.org/10.1016/S0016-7037(03)00371-5

Marescotti P., Carbone C., Comodi P., Frondini F. \& Lucchetti G., 2012 - Mineralogical and chemical evolution of ochreous precipitates from the Libiola $\mathrm{Fe}-\mathrm{Cu}$-sulfide mine (Eastern Liguria, Italy). Applied Geochemistry, 27: 577-589.

http://dx.doi.org/10.1016/j.apgeochem.2011.12.024 
Marini L., Saldi G., Cipolli F., Ottonello G. \& Vetuschi Zuccolini M., 2003 - Geochemistry of water discharges from the Libiola mine, Italy. Geochemical Journal, 37: 199-216. http://dx.doi.org/10.2343/geochemj.37.199

McFarlane D.A., Lundberg J. \& Belton F., 2004 - An unusual lava cave from Ol Doinyo Lengai, Tanzania. Journal of Cave and Karst Studies, 66: 98-101.

Nordstrom D.K., Alpers C.N., Ptacek C.J. \& Blowes D.W., 2000 - Negative $p H$ and extremely acidic mine waters from Iron Mountain California. Environmental Science Technology, 34: 254-258.

http://dx.doi.org/10.1021/es990646v

Northup D.E. \& Lavoie K.H., 2001 - Geomicrobiology of caves: a review. Geomicrobiology Journal, 18: 199-222. http:/ /dx.doi.org/10.1080/01490450152467750

Onac B.P. \& Forti, P., 2011 - State of the art and challenges in cave minerals studies. Studia UBB Geologia, 56: 33-42. http://dx.doi.org/10.5038/1937-8602.56.1.4

Onac B.P., Mylroie J.E. \& White W.B., 2001 - Mineralogy of cave deposits on San Salvador island, Bahamas. Carbonates and Evaporites, 16: 8-16. http://dx.doi.org/10.1007/BF03176222

Onac B.P., Fornós J.J., Merino A., Ginés J. \& Diehl J., 2014 - Linking mineral deposits to speleogenetic processes in Cova des Pas de Vallgornera (Mallorca, Spain). International Journal of Speleology, 43 (2): 143-157. http://dx.doi.org/10.5038/1827-806X.43.2.4

Onac B.P., Veres D.S., Kearns J., Chirienco M., Minut A. \& Breban R., 2003 - Secondary sulfates found in an old adit from Roşia Montană, Romania. Studia UBB Geologia, 48 (1): 29- 44. http://dx.doi.org/10.5038/1937-8602.48.1.3

Perrette Y. \& Jaillet S., 2010 - Spatial distribution of soda straws growth rates of the Coufin Cave (Vercors, France). International Journal of Speleology, 39 (2): 61-70. http://dx.doi.org/10.5038/1827-806X.39.2.2

Peterson R.C., 2003 - The relationship between $C u$ content and distortion in the atomic structure of melanterite from the Richmond mine, Iron Mount ain, California. The Canadian Mineralogist, 41: 937-949.

http://dx.doi.org/10.2113/gscanmin.41.4.937

Piccardo G. B., 2016 - Evolution of the lithospheric mantle during passive rifting: Inferences from the AlpineApennine orogenic peridotites. Gondwana Research. http://dx.doi.org/10.1016/j.gr.2016.03.001
Piccardo G.B., Rampone E. \& Romairone A., 2002 Formation and composition of the oceanic lithosphere of the Ligurian Tethys: inferences from the Ligurian ophiolites. Ofioliti, 27: 145-161.

Ponthieu M., Juillot F., Hiemstra T., van Riemsdijk W.H. \& Benedetti M.F., 2006 - Metal ion binding to iron oxides. Geochimica et Cosmochimica Acta, 70: 2679-2698.

http://dx.doi.org/10.1016/j.gca.2006.02.021

Schwertmann U., Friedl J. \& Stanjek H., 1999 - From $\mathrm{Fe}(\mathrm{III})$ ions to ferrihydrite and then to hematite. Journal of Colloidal Interface Science, 209: 215-223. http://dx.doi.org/10.1006/jcis.1998.5899

Spear J.R., Barton H.A., Robertson C.E., Francis C.A. \& Pace N.R., 2007 - Microbial community biofabrics in a geothermal mine adit. Applied and Environmental Microbiology, 73 (19): 6172-6180.

http://dx.doi.org/10.1128/AEM.00393-07

Tisato N., Torriano S.F.F., Monteux S., Sauro F., De Waele J., Tavagna M.L., D’Angeli I.M., Chailloux D., Renda M., Eglinton T.I. \& Bontognali T.R.R., 2015 Microbial mediation of complex subterranean mineral structures. Scientific Reports, 5: article 15525. http://dx.doi.org/10.1038/srep15525

Tuccimei P., Giordano G. \& Tedeschi M., $2006-\mathrm{CO}_{2}$ release variations during the last 2000 years at the Colli Albani volcano (Roma, Italy) from speleothems studies. Earth and Planetary Science Letters, 243: 449-462. http:/ / dx.doi.org/10.1016/j.eps1.2006.01.009

Wolery T., 1992 - EQ3NR, A Computer Program for Geochemical Aqueous Speciation-solubility Calculations: Theoretical Manual, users Guide and Related Documentation (version 7.0). Report UCRL-MA-110662 PT III. Lawrence Livermore National Laboratory, Livermore.

Yu J., Heo B., Choi I., Cho J. \& Chang H., 1999 - Apparent solubilities of schwertmannite and ferrihydrite in natural stream waters polluted by mine drainage. Geochimica et Cosmochimica Acta, 63: 3407-3416. http://dx.doi.org/10.1016/S0016-7037(99)00261-6

Zaccarini F. \& Garuti G., 2008 - Mineralogy and chemical composition of VMS deposits of northern Apennine ophiolites, Italy: evidence for the influence of country rock type on ore composition. Mineralogy and Petrology, 84: 61-83. http://dx.doi.org/10.1007/s00710-008-0010-9 